\title{
Genetic Variation in the Renin- Angiotensin System and Response to Endurance Training
}

\author{
Joon Seol Bae ${ }^{a}$ Byung Yong Kang ${ }^{b}$ Kang Oh Lee ${ }^{b}$ Seung-Taek Lee ${ }^{a}$ \\ ${ }^{a}$ Department of Biochemistry, College of Science, Yonsei University, and ${ }^{b}$ Research Institute for Life Science, \\ Sahmyook University, Seoul, Republic of Korea
}

\section{Key Words}

Renin-angiotensin system • Physical training •

Polymorphism

\begin{abstract}
Objective: To investigate the relationship between genetic variation in the renin-angiotensin system and the effect of 12 -week endurance training in Korean women. Materials and Methods: Seventeen women who participated in an endurance training program for 12 weeks were genotyped for the angiotensinogen M235T polymorphism, angiotensin II type 1 receptor $\mathrm{A} 1166 \mathrm{C}$ polymorphism, angiotensin-converting enzyme (ACE) T-3892C polymorphism, and angiotensin II type 2 receptor C3123A polymorphism. The following clinical parameters were measured before and after the endurance training program: blood pressure, body composition, ventilatory response, total cholesterol, triglyceride, and glucose. Results: Of the genetic markers investigated, the frequency of the T allele for the ACE T-3892C polymorphism was significantly associated with the response in body mass index and $\mathrm{VO}_{2 \text { max }}$ after 12 weeks of endurance training $(p<0.05)$. None of the other polymorphisms were significantly associated with the effect of training. Conclusion: The significant association between ACET-3892C and the change in body mass index and $\mathrm{VO}_{2 \text { max }}$ in Korean women are attributed to training, suggesting that this genetic variation is a useful genetic marker for clarifying the interindividual response to endurance training. Copyright $\odot 2007$ S. Karger AG, Basel
\end{abstract}

\section{KARGER \\ Fax +41613061234 \\ E-Mail karger@karger.ch}

www.karger.com
(C) 2007 S. Karger AG, Basel

1011-7571/07/0162-0142\$23.50/0

Accessible online at:

www.karger.com/mpp

\section{Introduction}

Data from many epidemiological studies have shown that endurance training has protective effects against cardiovascular risk factors in human health. Nevertheless, there is large variation in the physiological responses of participants when they perform the same endurance training. There is reasonable agreement regarding the suggestion that this variation in response is genetically mediated, at least in part. For example, Hagberg et al. [1] reported that systolic blood pressure (SBP) decreased with training in subjects who had the II or ID genotype of the angiotensin I-converting enzyme (ACE) gene or the E3 or E4 genotype of the apolipoprotein E gene. Recently, Delmonico et al. [2] also reported that resting blood pressure was reduced to a greater extent in C-allele carriers of angiotensinogen (AGT) A-20C and angiotensin II type 1 receptor $\left(\mathrm{AT}_{1} \mathrm{R}\right) \mathrm{A} 1166 \mathrm{C}$ than in A homozygotes in response to strength training.

The renin-angiotensin system (RAS) has an important role in blood pressure homeostasis, and the component genes of the RAS include those encoding AGT, ACE, $\mathrm{AT}_{1} \mathrm{R}$, and the angiotensin II type 2 receptor $\left(\mathrm{AT}_{2} \mathrm{R}\right)$. Angiotensin I is produced from AGT by renin, and it is subsequently converted into angiotensin II by ACE. Angiotensin II increases blood pressure by causing vasoconstriction, aldosterone secretion, and sodium/water reabsorption in the kidney. The cellular effects of angiotensin II are mediated by two structurally distinct receptor sub- 
Table 1. Primer sequences used for PCR amplification of the candidate genes

\begin{tabular}{|c|c|c|c|c|c|c|}
\hline Gene & $\begin{array}{l}\text { Polymor- } \\
\text { phic site }\end{array}$ & Primer sequence & $\begin{array}{l}\mathrm{T}_{\mathrm{A}} \\
{ }^{\circ} \mathrm{C}^{\mathrm{a}}\end{array}$ & $\begin{array}{l}\text { Fragment } \\
\text { size, bp }\end{array}$ & $\mathrm{RE}^{\mathrm{b}}$ & $\begin{array}{l}\text { Refer- } \\
\text { ence }\end{array}$ \\
\hline AGT & M235T & $\begin{array}{l}5^{\prime} \text {-CAGGGTGCTGTCCACACTGGACCCC-3' } \\
5^{\prime} \text {-CCCTTTGTGCAGGGCCTGGCTCTCT-3' }\end{array}$ & 53 & $141 / 24$ & ThlIII & 7 \\
\hline $\mathrm{ACE}$ & $\mathrm{T}-3892 \mathrm{C}$ & $\begin{array}{l}5^{\prime} \text {-ATAGTGTATATAGGGCTTGGTAC-3' } \\
5^{\prime} \text {-GAAGATATTTGCAAAGTATGTACTG-3' }\end{array}$ & 55 & $114 / 90$ & Pst I & 8 \\
\hline $\mathrm{AT}_{1} \mathrm{R}$ & A1166C & $\begin{array}{l}\text { 5'-ATAATGTAAGCTCATCCACCAAGAAG-3' } \\
5^{\prime} \text {-TCTCCTTCAATTCTGAAAAGTACTTAA-3' }\end{array}$ & 50 & $139 / 27$ & AflII & 9 \\
\hline $\mathrm{AT}_{2} \mathrm{R}$ & C3123A & $\begin{array}{l}\text { 5'-GGATTCAGATTTCTCTTTGAA-3' } \\
5^{\prime} \text {-GCATAGGAGTATGATTTAATC-3' }\end{array}$ & 53 & $214 / 107$ & AluI & 10 \\
\hline
\end{tabular}

\footnotetext{
${ }^{a}$ Annealing temperature for PCR.

${ }^{\mathrm{b}}$ Restriction endonuclease.
}

types, $\mathrm{AT}_{1} \mathrm{R}$ and $\mathrm{AT}_{2} \mathrm{R}$. With respect to the $\mathrm{ACE}$ gene, several studies have reported that the I allele is associated with enhanced improvement in cardiovascular risk factors after endurance training and is more common in endurance athletes than in sedentary controls [3]. The I allele has been associated with improved capacity to perform repetitive elbow flexion after a physical training program [4]. The AGT M235T polymorphism is reported to be associated with the variability in left ventricular hypertrophy induced by endurance training, with athletes homozygous for the T allele having the largest hearts [5]. Until now, such studies have mainly examined Caucasian populations, and no study has attempted to correlate the genetic polymorphisms of the RAS genes with various physiological effects before and after endurance training in an ethnically homogeneous Korean population.

The association between the improvement in cardiovascular risk factors after endurance training and the presence of each of four common allelic polymorphisms in the RAS, namely ACE T-3892C, AGT M235T, AT $\mathrm{A}_{1}$ $\mathrm{A} 1166 \mathrm{C}$, and $\mathrm{AT}_{2} \mathrm{R} \mathrm{C} 3123 \mathrm{~A}$, was investigated. The last two were included to determine whether these polymorphisms might be associated with the effects of an endurance training program.

\section{Materials and Methods}

\section{Study Subjects}

Seventeen unrelated individuals (age: $53 \pm 6.52$ years) from Seoul Hygiene Hospital, Seoul, Korea, were selected to participate in a 12 -week endurance training program. None of the participants had a history of hypertension, coronary artery disease, diabetes mellitus, or obesity.

Relationship between RAS and Physical Training

\section{Endurance Exercise Training Program}

During the first 2 weeks, training was carried out at a heart rate that corresponded to $55 \%$ of the baseline $\mathrm{VO}_{2 \max }$ for $30 \mathrm{~min}$ per session. The duration and intensity of the training sessions were gradually increased to $50 \mathrm{~min}$ and $75 \%$ of the heart rate associated with the baseline $\mathrm{VO}_{2 \max }$, which were then sustained until the last week. The average training frequency was three times per week, and all training was performed on cycle ergometers under supervision in the laboratory [6].

\section{Determination of Anthropometric and Biochemical}

\section{Parameters}

Blood samples were obtained in EDTA-tubes from subjects who had fasted for 12-16 h. A sphygmomanometer was used to measure systolic and diastolic blood pressures (SBP and DBP, respectively). The mean arterial pressure was calculated as [DBP$1 / 3(\mathrm{SBP}-\mathrm{DBP})] \mathrm{mm} \mathrm{Hg}$. The $\mathrm{VO}_{2 \max }$ was measured during motor-driven treadmill exercise tests. The body mass index (BMI) was calculated by dividing the body weight $(\mathrm{kg})$ by the square of the height $\left(\mathrm{m}^{2}\right)$. The concentrations of total cholesterol (TCH) and triglyceride (TG) were measured by enzymatic colorimetric methods using a commercial kit (Boehringer Mannheim, Germany) and a chemistry analyzer.

\section{Genotype Analysis of the Four RAS Polymorphisms}

Genomic DNA was isolated from buffy coats prepared from blood $(5 \mathrm{ml})$. Polymerase chain reaction (PCR)-restriction fragment length polymorphism techniques were used to examine the AGT M235T, ACE T-3892C, $\mathrm{AT}_{1} \mathrm{R}$ A1166C, and $\mathrm{AT}_{2} \mathrm{R}$ C3123A gene polymorphisms. Briefly, each $50-\mu$ l reaction mixture contained 200-400 ng of extracted genomic DNA, $100 \mathrm{ng}$ of each primer, $200 \mu \mathrm{M}$ of each of four dNTPs, and the reaction buffer recommended by the manufacturer. The primer sequences, annealing temperatures for the PCR reaction, fragment sizes, and restriction endonucleases used for the four polymorphisms are shown in table 1 . Each PCR reaction was performed in $50 \mu \mathrm{l}$ containing $0.1 \mathrm{mM}$ each of dCTP, dATP, dGTP, and dTTP; $10 \mathrm{pmol}$ of each oligonucleotide primer; $10 \mathrm{mM}$ Tris- $\mathrm{HCl}(\mathrm{pH} 8.3) ; 50 \mathrm{mM}$ $\mathrm{KCl} ; 1.5 \mathrm{mM} \mathrm{MgCl}_{2} ; 0.01 \%$ gelatin; 1.25 units of Taq DNA poly- 
Table 2. Clinical characteristics of the study subjects at baseline and after a 12 -week endurance training program

\begin{tabular}{|c|c|c|c|c|}
\hline Variable & $\begin{array}{l}\text { Baseline } \\
(\text { mean } \pm \mathrm{SD})\end{array}$ & $\begin{array}{l}12 \text { weeks } \\
(\text { mean } \pm \mathrm{SD})\end{array}$ & $\mathrm{t}$ value & $\begin{array}{l}\text { Proba- } \\
\text { bility }\end{array}$ \\
\hline SBP, mm Hg & $60.7 \pm 10.2$ & $59.3 \pm 9.9$ & 3.862 & $0.001^{*}$ \\
\hline $\mathrm{DBP}, \mathrm{mm} \mathrm{Hg}$ & $80.2 \pm 9.9$ & $76.3 \pm 8.7$ & 2.104 & 0.051 \\
\hline Weight, kg & $60.7 \pm 10.0$ & $59.3 \pm 9.9$ & 3.722 & $0.002^{*}$ \\
\hline BMI & $25.6 \pm 4.5$ & $25.0 \pm 4.3$ & 3.877 & $0.001^{*}$ \\
\hline $\mathrm{VO}_{2 \max }, \mathrm{ml} / \mathrm{kg} / \mathrm{min}$ & $24.1 \pm 4.6$ & $27.7 \pm 4.5$ & -5.179 & $0.000^{*}$ \\
\hline $\mathrm{TG}, \mathrm{mg} / \mathrm{dl}$ & $163.7 \pm 43.3$ & $110.5 \pm 29.6$ & 5.672 & $0.000^{*}$ \\
\hline $\mathrm{TCH}, \mathrm{mg} / \mathrm{dl}$ & $218.1 \pm 57.6$ & $194.1 \pm 38.6$ & 2.042 & 0.057 \\
\hline Glucose, mg/dl & $115.9 \pm 32.1$ & $101.8 \pm 27.3$ & 2.812 & $0.012^{*}$ \\
\hline
\end{tabular}

Table 3. Clinical characteristics at baseline and in response to a 12 -week endurance training program according to the genotype of the ACE T-3925C polymorphism

\begin{tabular}{lcc}
\hline Variable & Genotypes & \\
\cline { 2 - 3 } & $\mathrm{TT}(5)$ & $\mathrm{TC}+\mathrm{CC}(12)$ \\
\hline SBP, mm Hg & & \\
Baseline & $126.8 \pm 17.9$ & $133.4 \pm 7.0$ \\
Response & $-4.8 \pm 7.0$ & $-9.6 \pm 10.4$ \\
\hline DBP, mmHg & & \\
Baseline & $77.2 \pm 8.8$ & $81.0 \pm 10.8$ \\
Response & $-1.0 \pm 7.9$ & $-3.4 \pm 5.6$ \\
\hline Weight, kg & & \\
Baseline & $56.8 \pm 6.1$ & $63.1 \pm 11.0$ \\
Response & $-0.3 \pm 2.5$ & $-1.9 \pm 1.0$ \\
\hline BMI & & \\
Baseline & $22.9 \pm 3.6$ & $27.1 \pm 4.4$ \\
Response* & $0.1 \pm 1.0$ & $0.9 \pm 0.4$ \\
\hline VO ${ }_{2 m a x}, \mathrm{ml} / \mathrm{kg} / \mathrm{min}$ & & \\
Baseline & & \\
Response* & $25.1 \pm 5.8$ & $23.8 \pm 4.4$ \\
\hline TG, mg/dl & $6.1 \pm 3.5$ & $2.6 \pm 2.3$ \\
Baseline & & \\
Response & $10.8 \pm 82.7$ & $-36.9 \pm 24.3$ \\
\hline TCH, mg/dl & $-18.6 \pm 33.2$ & $-12.8 \pm 16.7$ \\
Baseline & & \\
Response & & \\
\hline Glucose, $\mathrm{mg} / \mathrm{dl}$ & & \\
Baseline & & \\
Response & & \\
\hline
\end{tabular}

Values are expressed as mean \pm SD. ${ }^{*} \mathrm{p}<0.05$.

Baseline signifies value before starting the 12 -week endurance training. Response signifies difference between the pre- and posttraining values. merase (Perkin-Elmer/Cetus), and 100 ng genomic DNA. Amplification was carried out for 30 cycles of denaturation at $94^{\circ} \mathrm{C}$ for $1 \mathrm{~min}$, annealing at the temperatures listed in table 1 for $1 \mathrm{~min}$, and extension at $72^{\circ} \mathrm{C}$ for $1 \mathrm{~min}$ in a PTC-200 thermocycler (MJ Research, USA). After the PCR reaction, about $10 \mu$ l of each PCR product was digested using the appropriate restriction enzyme, and the genotype was determined from ethidium bromidestained agarose gels or polyacrylamide gels after electrophoresis. For the AGT gene, the M allele has a 165-bp PCR product, and the $\mathrm{T}$ allele has 141- and 24-bp fragments. For the ACE gene, the T allele has a 204-bp band, and the C allele has 114- and 90-bp fragments. For the $\mathrm{AT}_{1} \mathrm{R}$ gene, the $\mathrm{A}$ allele has a 166-bp product, and the $\mathrm{C}$ allele has 129- and 27-bp fragments. For the $\mathrm{AT}_{2} \mathrm{R}$ gene, the $\mathrm{C}$ allele has a 321-bp fragment, and the A allele has 214- and 107-bp fragments.

\section{Statistical Analysis}

All statistical analyses were performed using SPSS for Windows version 11.0 (SPSS, Chicago, Ill., USA). The significance of differences in allele frequencies between the study groups was estimated using the $\chi^{2}$ test. One-way ANOVA was used to compare the mean values of biochemical parameters among different genotypes. Allele frequencies were estimated using the gene counting method. Deviation in the genotype distribution from that expected for Hardy-Weinberg equilibrium was estimated using the $\chi^{2}$-fit test. An independent I test was used to compare baseline values and the responses to exercise training between genotype groups. Paired t tests were used to assess the significance of exercise training-induced changes in all variables within genotype groups. A $\mathrm{p}$ value of less than 0.05 was considered significant.

\section{Results}

The clinical characteristics of the study subjects at baseline and the response after finishing the 12-week endurance training program are shown in table 2. SBP, weight, $\mathrm{BMI}, \mathrm{VO}_{2 \max }$, $\mathrm{TG}$, and glucose were significantly different after 12 weeks of endurance training $(\mathrm{p}<0.05)$. Of these parameters, $\mathrm{VO}_{2 \max }$ was increased, whereas the 
others were reduced. The observed genotype distribution of the four polymorphisms did not deviate from HardyWeinberg equilibrium. For the ACE T-3892C polymorphism, the observed genotype frequencies of TT, TC, and CC were $29.4,58.8$ and $11.8 \%$, respectively, and the frequency of the $\mathrm{T}$ allele was 0.59 . For the $\mathrm{AT}_{2} \mathrm{R} \mathrm{C} 3123 \mathrm{~A}$ polymorphism, the observed genotype frequencies of CC, CA, and AA were 50.0, 33.3 and 16.7\%, respectively, and the frequency of the $\mathrm{C}$ allele was 0.68 . Both the AGT M235T and ACE T-3892C polymorphisms showed monomorphic patterns. The AGT M235T polymorphism only showed the Tallele, and the $\mathrm{AT}_{1} \mathrm{R} \mathrm{C} 3123 \mathrm{~A}$ polymorphism was always the A allele (data not shown). The response of the clinical parameters in the presence of the ACE $\mathrm{T}-3892 \mathrm{~T}$ polymorphism after the 12 -week endurance training program are shown in table 3 . The T-3892C polymorphism of the ACE gene was significantly associated with the $\mathrm{VO}_{2 \max }$ and BMI responses. The TG concentration was reduced after training, but this was not statistically significant. There were no significant associations between the $\mathrm{AT}_{2} \mathrm{R} C 3123 \mathrm{~A}$ polymorphism and any parameter after the 12 -week endurance training program.

\section{Discussion}

Although there have been many reports on the association between the genetic variations in the RAS genes and physical performance and cardiovascular disease in many populations $[3-5,11-16]$, there are few reports on the effects of these genetic polymorphisms on the improvement of cardiovascular risk through endurance training $[1,2]$. Nevertheless, several reports documented that genetic polymorphisms in the RAS genes, especially the ACE gene, were significantly associated with endurance performance in several populations. Gayagay et al. [17] first reported an association between I/D polymorphism in the ACE gene and athletic performance in an Australian population. However, other studies reported conflicting results about this issue among populations studied [3]. In this regard, our study investigated the effect of four polymorphisms of RAS genes on clinical parameters after a 12-week endurance training scheme in 17 Korean women. Of the genetic polymorphisms studied, we found a significant association between the ACE T-3892C polymorphism and the responses of $\mathrm{VO}_{2 \max }$ and BMI. Therefore, the ACE T-3892C polymorphism might modify the effect of endurance training on these parameters. Specifically, subjects with the TT genotype had a greater increase in $\mathrm{VO}_{2 \max }$ than subjects with the TC or CC genotype. In addition, those with the TT genotype had a greater reduction in BMI than those with the TC or CC genotype. Therefore, the effect of endurance training might be maximally improved in women with the TT genotype. The molecular mechanism of these observations is unclear, but the effect might be the result of linkage disequilibrium between this polymorphic site and an unidentified functional allele. A promoter assay might clarify the function of this polymorphism. There was no association between the $\mathrm{AT}_{2} \mathrm{R}$ C3123A polymorphism and the clinical parameters. However, our study must be regarded as preliminary because of the small sample size. Future studies with more subjects are needed to clarify the interindividual susceptibility of the ACE T-3892C marker on improving cardiovascular risk through endurance training.

\section{Conclusion}

The presence of both the ACE T-3892C and $\mathrm{AT}_{2} \mathrm{R}$ C3123A polymorphisms resulted in reduced SBP, DBP, weight, BMI, TG, TCH and glucose, and increased $\mathrm{VO}_{2 \max }$ after endurance training. Specifically, the ACE T-3892C polymorphism was significantly associated with the changes in both $\mathrm{VO}_{2 \max }$ and $\mathrm{BMI}$ after a 12-week endurance training program. 


\section{References}

>1 Hagberg JM, Ferrell RE, Dengel DR, Wilund KR: Exercise training-induced blood pressure and plasma lipid improvements in hypertensives may be genotype dependent. Hypertension 1999;34:18-23.

-2 Delmonico MJ, Ferrell RE, Meerasahib A, Martel GF, Roth SM, Kostek MC, Hurley BF: Blood pressure response to strength training may be influenced by angiotensinogen A20C and angiotensin II type I receptor A1166C genotype in older men and women. J Am Geriatr Soc 2005;53:204-210.

3 Rankinen T, Wolfarth B, Simoneau JA, Maier-Lenz D, Rauramaa R, Rivera MA, Boulay MR, Chagnon YC, Pérusse L, Keul J, Bouchard C: No association between the angiotensin-converting enzyme ID polymorphism and elite endurance athlete status. J Appl Physiol 2000;88:1571-1575.

$\checkmark 4$ Montgomery HE, Marshall RM, Hemingway $\mathrm{H}$ : Human gene for physical performance. Nature 1998;393:221-222.

$\checkmark 5$ Karjalainen J, Kujala UM, Stolt A, Mantysaari M, Viitasalo M, Kainulainen K, Kontula K: Angiotensinogen gene M235T polymorphism predicts left ventricular hypertrophy in endurance athletes. J Am Coll Cardiol 1999;34:494-499.

6 Skinner JS, Wilmore KM, Krasnoff JB, Jaskolski A, Jaskolska A, Gagnon J, Province MA, Leon AS, Rao DC, Wilmore JH, Bouchard C: Adaptation to a standardized training program and changes in fitness in a large, heterogeneous population: the HERITAGE Family Study. Med Sci Sports Exerc 2000;32: 157-161.
7 Russ AP, Maerz W, Ruzicka V, Stein U, Gross W: Rapid detection of the hypertension-associated Met235 $\rightarrow$ Thr allele of the human angiotensinogen gene. Hum Mol Genet 1993; 2:609-610.

8 Keavney B, McKenzie CA, Connell JM, Julier C, Ratcliffe PJ, Sobel E, Lathrop M, Farrall $\mathrm{M}$ : Measured haplotype analysis of the angiotensin-I converting enzyme gene. Hum Mol Genet 1998;7:1745-1751.

$\checkmark 9$ Hingorani AD, Brown MJ: A simple molecular assay for the C1166 variant of the angiotensin II type 1 receptor gene. Biochem Biophys Res Commun 1995;213:725-729.

10 Katsuya T, Horiuchi M, Minami S, Koike G, Santoro NF, Hsueh AJ, Dzau VJ: Genomic organization and polymorphism of human angiotensin II type 2 receptor: no evidence for its gene mutation in two families of human premature ovarian failure syndrome. Mol Cell Endocrinol 1997;127:221-228.

11 Williams AG, Rayson MP, Jubb M, World M, Woods DR, Hayward M, Martin J, Humphriest SE, Montgomery HE: The ACE gene and muscle performance. Nature 2000;403:614.
12 Alvarez R, Terrados N, Ortolano R, IglesiasCubero G, Reguero JR, Batalla A, Cortina A, Fernandez-Garcia B, Rodriguez C, Braga S, Alvarez V, Coto E: Genetic variation in the rennin-angiotensin system and athletic performance. Eur J Appl Physiol 2002;82:117120.

13 Taylor RR, Mamotte CD, Fallon K, van Bockxmeer FM: Elite athletes and the gene for angiotensin-converting enzyme. J Appl Physiol 1999;87:1035-1037.

14 Myerson S, Hemingway H, Budget R, Martin J, Humphries S, Montgomery H: Human angiotensin I-converting enzyme gene and endurance performance. J Appl Physiol 1999; 87:1313-1316.

15 Montgomery H, Clarkson P, Bernard M, Bell J, Brynes A, Dollery C, Hajnal J, Hemingway H, Mercer D, Jarman P, Marshall R, Prasad K, Rayson M, Saeed N, Talmud P, Thomas L, Jubb M, World M, Humphries S: Angiotensin-converting enzyme gene insertion/deletion polymorphism and response to physical training. Lancet 1999;353:541-545.

16 Nazarov IB, Woods DR, Montgomery HE, Shneider OV, Kazakov VI, Tomilin NV, Rogozkin VA: The angiotensin converting enzyme I/D polymorphism in Russian athletes. Eur J Hum Genet 2001;9:797-801.

17 Gayagay G, Yu B, Hambly B, Boston T, Hahn A, Celermajer DS, Trent RJ: Elite endurance athletes and the ACE I allele-the role of genes in athletic performance. Hum Genet 1998; 103:48-50. 